\title{
Pathogenicity of Steinernema brazilense (Rhabditida: Steinernematidae) to Gonipterus platensis (Coleoptera: Curculionidae) prepupae
}

\author{
A. L. Brida ${ }^{a}$ (D) M. C. Candelaria ${ }^{a}$, B. M. C. Castro C (D) L. G. Leite $^{c}$ (D) S. R. S. Wilcken ${ }^{a}$ (D), \\ J. C. Zanuncio ${ }^{d}$ (D) and C. F. Wilcken ${ }^{a}$ \\ aDepartamento de Produção Vegetal, Universidade Estadual Paulista “Júlio de Mesquita Filho" - UNESP, CEP 18603-970, \\ Botucatu, SP, Brasil

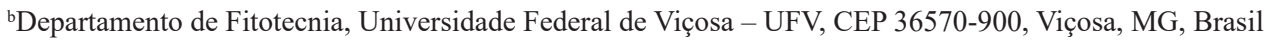 \\ ${ }^{c}$ Centro Experimental, Instituto Biológico, CEP 13001-970, Campinas, SP, Brasil \\ ${ }^{\text {d} D e p a r t a m e n t o ~ d e ~ E n t o m o l o g i a, ~ I n s t i t u t o ~ d e ~ B i o t e c n o l o g i a ~ A p l i c a d a ~ a ̀ ~ A g r o p e c u a ́ r i a ~-~ B I O A G R O, ~ U n i v e r s i d a d e ~ F e d e r a l ~}$ \\ de Viçosa - UFV, CEP 36570-900, Viçosa, MG, Brasil \\ *e-mail: barbaramcastro@hotmail.com
}

Received: June 5, 2019 - Accepted: October 11, 2019 - Distributed: February 28, 2021

(With 1 figure)

\section{Introduction}

The genus Gonipterus Marelli, 1927 (Gonipterinae: Curculionidae) has about 20 species known as Eucalyptus weevils or Eucalyptus snout-beetles (Mapondera et al., 2012). The weevil G. platensis was the first introduced eucalyptus pest in New Zealand (1890), Africa (1916), South America (1925), Europe (1975) and North America (1994) (Mapondera et al., 2012). The introduction of key pests as G. platensis and Thaumastocoris peregrinus Carpintero \& Dellapé (Hemiptera: Thaumastocoridae) is a risk to forest plantations (Reis et al., 2012; Almeida et al., 2018), such as those of eucalypts (Bhattacharya et al., 2003; Clarke et al., 1998). Adults and larvae of the eucalyptus weevil feed preferably on young leaves, buds and developing shoots causing high damage (Clarke et al., 1998). G. platensis is the main eucalypt pests in many regions (Reis et al., 2012) and its impact and that of other eucalyptus weevils is poorly studied, mainly due to the difficulties of identifying control factors influencing this crop productivity (Reis et al., 2012).

The egg parasitoid Anaphes nitens (Girault, 1928) (Hymenoptera: Mymaridae) has been used for the biological control of G. platensis (Hanks et al., 2000), but this pest has been causing high damage levels (Echeverri-Molina and Santolamazza-Carbone, 2010). The life cycle of entomopathogenic nematodes in the soil make them promising biological control agents of insects with part of its life cycle in the soil as eucalyptus weevils (Barbosa-Negrisoli et al., 2010; Grewal, 2000) including G. platensis.

Nematodes of the order Rhabditida (Steinernematidae and Heterorhabditidae) can kill insects due to its mutualistic association with Xenorhabdus and Photorhabdus bacteria (Poinar Junior and Grewal, 2012). These bacteria kill hosts by septicemia in 24 to $48 \mathrm{~h}$ and they are been studied to manage insect pests (Poinar Junior and Grewal, 2012). Heterorhabditis amazonensis (Rhabditida: Heterorhabditidae) was isolated from soil samples in Amazonas (Andaló et al., 2006) and Steinernema brazilense in Mato Grosso, Brazil
(Nguyen et al., 2010). In addition, H. amazonensis, S. rarum, Oscheios tipulae, Metarhabditis rainai, were reported in agriculture and native vegetation areas in different Brazilian regions (Brida et al., 2017).

The adaption to new environments and host searching efficiency (Shapiro-Ilan et al., 2005; Achinelly et al., 2016) reinforce the entomopathogenic nematode potential (EPNs) to manage agriculture and forest pests. Steinernema and Heterorhabditis species (Rhabditida: Steinernematidae/Heterorhabditidae) (Smits, 1996) are efficient against Curculionidae (Manachini et al., 2013). Steinernema and Heterorhabditis genera were virulent to Sphenophorus levis Vaurie (Coleoptera: Curculionidae) adults (Giometti et al., 2011). Gonipterus platensis larvae and adults feed on leaves and pupate in the soil when they may have contact with entomopathogenic nematodes.

The objective of this study was to evaluate the pathogenicity of $S$. brazilense to G. platensis prepupae.

\section{Material and Methods}

The experiment was conducted at the Laboratory of Agricultural Nematology of the São Paulo State University (UNESP) in Botucatu, São Paulo state, Brazil. Steinernema brazilense was obtained from the Entomopathogenic Nematode Collection of the Entomopathogens "Oldemar Cardim Abreu" Bank of the Biological Institute of São Paulo, São Paulo, Brazil.

Infective juveniles (IJs) of $S$. brazilense IBCBn 06 were multiplied in D. saccharalis (third to fifth instar) larvae (Woodring and Kaya, 1988). Five larvae per Petri dish (9-cm diam) lined with filter paper moistened with a suspension of nematodes at the concentration of $500 \mathrm{IJs} / \mathrm{cm}^{2}$ of Petri dish surface was used. Dead $D$. saccharalis larvae were transferred to white trap (White, 1927) and stored in chamber at $25^{\circ} \mathrm{C}, 70 \pm 80 \% \mathrm{RH}$, in the dark. IJs were obtained from this host and collected in a water film 
( $1 \mathrm{~cm}$ deep) in Erlemeyers maintained in BOD chamber at $18{ }^{\circ} \mathrm{C}, 70 \pm 80 \% \mathrm{RH}$ and used two days after collection. The $G$. platensis prepupae were collected in a eucalyptus plantation in Itatinga (2311'35.1'S 48 38'32.5”W) São Paulo state, Brazil.

The nematode $S$. brazilense IBCBn 06 pathogenicity to G. platensis prepupae (Woodring and Kaya, 1988) was evaluated in two treatments with five replications, each with four prepupae of this insect per Petri dish $(9 \mathrm{~cm})$. Two $\mathrm{mL}$ of the suspension of this isolate was applied in aqueous suspension with a pipette, equivalent to a dose of $500 \mathrm{IJ} /$ insect $\left(125 \mathrm{IJ} / \mathrm{cm}^{2}\right)$ per dish with bottom lined with two filter paper sheets. The control treatment had $2 \mathrm{~mL}$ of distilled water per dish. The nematode pathogenicity was evaluated with $D$. saccharalis pupae (Woodring and Kaya, 1988). Petri dishes were sealed with transparent PVC plastic film and stored in BOD chamber at $26^{\circ} \mathrm{C}$ and $70 \% \mathrm{RH}$ in the dark. Dead and live insects were counted after $4 \mathrm{~d}$. Prepupae of $G$. platensis and D. saccharalis were rinsed in tap water and individually kept in new Petri dishes $(5 \mathrm{~cm})$ with a moistened filter paper for dissection. The number of insect adults, dead prepupae and IJs second generation was quantified under a stereomicroscope.

\section{Results and Discussion}

Steinernema brazilense IBCBn 06 killed all G. platensis prepupae at $4 \mathrm{~d}$ after inoculation with infection rates of $10.3 \mathrm{IJs}$, and a total of 1275.7 IJs produced in the second generation. The $D$. saccharalis pupae parasitism was $100 \%$ with infection rate of 15.5 , and a total of 7201.9 second generation IJs, proving the high entomopathogenic viability

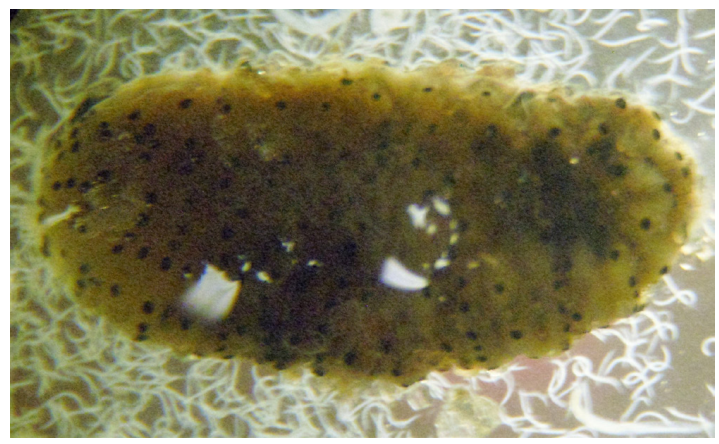

Figure 1. Gonipterus platensis (Coleoptera: Curculionidae) prepupae infected by Steinernema brazilense IBCBn 06. of this nematode. No mortality of G. platensis prepupae and $D$. saccharalis pupae was recorded in the controls (Table 1, Figure 1).

The $100 \%$ mortality of G. platensis prepupae by $S$. brazilense indicates high susceptibility of this weevil stage to parasitism by this nematode. The $S$. brazilense IBCBn 06 pathogenicity was previously reported to important Curculionidae pests as Anthonomus grandis (Boheman) (Coleoptera; Curculionidae) (Enrique Cabanillas, 2003), Diaprepes abbreviatus (Linnaeus) (Coleoptera: Curculionidae) (Duncan et al., 2003), Curculio caryae (Horn) (Coleoptera: Curculionidae) (Shapiro-Ilan et al., 2005). Steinernematidae nematodes live in symbiotic association with bacteria of the genus Xenorhabdus (Poinar Junior and Grewal, 2012), responsible for host death and decomposition of their tissues which are used as food for the development this natural enemies (Nermut et al., 2019). Informations on EPNs pathogenicity is important to integrated pest management success (Andaló et al., 2014; Brown and Martin, 2014).

The lower production of $S$. brazilense IBCBn 06 IJs in $G$. platensis pupae than in those of $D$. saccharalis may be due to the larger size of this nematode. This may have caused space and food limitations and a lower offspring number in the first host. The 7201.9 IJs of this nematode produced per $D$. saccharalis pupae confirms results for $H$. indica IBCBn 05 in Mahanarva fimbriolata (Stål) (Hemiptera: Cercopidae) nymphs (Leite et al., 2003). S. brazilense was pathogenic and to G. platensis prepupae, however, with a lower production of IJs per host compared to that found with G. mellonella larvae with up to 200000 IJs of this microorganism (Dutky et al., 1964).

The nematode $S$. brazilense IBCBn 06 parasitized and killed $100 \%$ of G. platensis prepupae, showing potential for integrated management of this eucalyptus weevil.

\section{Acknowledgements}

To "Conselho Nacional de Desenvolvimento Científico e Tecnológico (CNPq)", "Fundação de Amparo à Pesquisa do Estado de Minas Gerais (FAPEMIG)", "Fundação de Amparo à Pesquisa do Estado de São Paulo (FAPESP)" and "Programa de Proteção Florestal (PROTEF)" of the "Instituto de Pesquisas e Estudos Florestais (IPEF)" for financial support. To Dr. José A. S. Rodrigues (EMBRAPA Milho e Sorgo) and Agropecuária Ipê, Campo Mourão, Paraná, for providing the seeds. Global Edico Services corrected and edited the English of this manuscript.

Table 1. Mortality (\%) of Gonipterus platensis prepupae (Coleoptera: Curculionidae) and Diatraea saccharalis (Crambidae: Lepidoptera) pupae by Steinernema brazilense IBCBn 06, number of infecting juveniles (No. IJs) and those produced on the second generation within the host $\left(2^{\text {nd }}\right.$ generation $)$.

\begin{tabular}{lccc}
\hline \multicolumn{1}{c}{ Insect } & Mortality (\%) & No. IJs \pm SE & 2 $^{\text {nd }}$ generation \pm SE \\
\hline Gonipterus platensis & 100 & $10.3 \pm 2.01$ & $1275.7 \pm 474.15$ \\
Diatraea saccharalis & 100 & $15.5 \pm 4.78$ & $7201.9 \pm 2355.88$ \\
Gonipterus platensis (control) & 0 & 0 & 0 \\
Diatraea saccharalis (control) & 0 & 0 & 0 \\
\hline
\end{tabular}

IJs = Infective juveniles; SE $=$ Standard error. 


\section{References}

ACHINELLY, M.F., ELICECHE, D.P., BELAICH, M.N. and GHIRINGHELLI, P.D., 2016. Variability study of entomopathogenic nematode populations (Heterorhabditidae) from Argentina. Brazilian Journal of Biology $=$ Revista Brasileira de Biologia, vol. 77, no. 3, pp. 569-579. http://dx.doi.org/10.1590/1519-6984.20015. PMid:27783765.

ALMEIDA, K.E.C., SILVA, J.G.S., SILVA, I.M.A., COSTA, A.L. and LAIA, M.L., 2018. Ecophysiological analysis of Eucalyptus camaldulensis (Dehnh) submitted to attack from Thaumastocoris peregrinus (CARPINTERO \& DELLAPE). Revista Árvore, vol. 42, no. 1, pp. e420120. http://dx.doi.org/10.1590/180690882018000100020

ANDALÓ, V., MOINO, A. and NGUYEN, K., 2006. Heterorhabditis amazonensis $\mathrm{n}$. sp. (Rhabditida: Heterorhabditidae) from Amazonas, Brazil. Nematology, vol. 8, no. 6, pp. 853-867. http://dx.doi. org/10.1163/156854106779799286.

ANDALÓ, V., MOREIRA, G.F. and MOINO JUNIOR, A., 2014. Heterorhabditis amazonensis RSC5 (Rhabditida: Heterorhabditidae) movement and host recognition. Revista Colombiana de Entomologia, vol. 40, no. 1, pp. 91-97.

BARBOSA-NEGRISOLI, C.R.C., GARCIA, M.S., DOLINSKI, C., NEGRISOLI JUNIOR, A.S., BERNARDI, D. and SANTOS, F.J., 2010. Survey of entomopathogenic nematodes (Rhabditida: Heterorhabditidae, Steinernematidae) in Rio Grande do Sul State, Brazil. Nematologia Brasileira, vol. 34, no. 4, pp. 189-197. http:// dx.doi.org/10.1016/j.jip.2009.05.005. PMid:19460384.

BHATTACHARYA, S.C., SALAM, P.A., PHAM, H.L. and RAVINDRANATH, N.H., 2003. Sustainable biomass production for energy in selected Asian countries. Biomass and Bioenergy, vol. 25, no. 5, pp. 471-482. http://dx.doi.org/10.1016/S09619534(03)00085-0.

BRIDA, A.L., ROSA, J.M., OLIVEIRA, C.M., CASTRO, B.M., SERRÃO, J.E., ZANUNCIO, J.C., LEITE, L.G. and WILCKEN, S.R., 2017. Entomopathogenic nematode in agricultural areas in Brazil. Scientific Reports, vol. 7, no. 1, pp. 45254. http://dx.doi. org/10.1038/srep45254. PMid:28382937.

BROWN, A.P. and MARTIN, G., 2014. Commercial examples of the use of entomopathogenic nematodes in integrated pest management (IPM) programs. Journal of Nematology, vol. 46, no. 2, pp. 141-142.

CLARKE, A.R., PATERSON, S. and PENNINGTON, P., 1998. Gonipterus scutellatus Gyllenhal (Coleoptera: Curculionidae) oviposition on seven naturally co-occurring Eucalyptus species. Forest Ecology and Management, vol. 110, no. 1-3, pp. 89-99. http://dx.doi.org/10.1016/S0378-1127(98)00277-1.

DUNCAN, L.W., DUNN, D.C., BAGUE, G. and NGUYEN, K.B., 2003. Competition between entomopathogenic and freeliving bacterivorous nematodes in larvae of the weevil Diaprepes abbreviatus. Journal of Nematology, vol. 35, no. 2, pp. 187-193. PMid:19265993.

DUTKY, S.R., THOMPSON, J.V. and CANTWELL, G.G.A., 1964. Technique for the mass propagation of the DD-136 nematode. Journal of Invertebrate Pathology, vol. 6, no. 4, pp. 417-422.

ECHEVERRI-MOLINA, D. and SANTOLAMAZZA-CARBONE, S., 2010. Toxicity of synthetic and biological insecticides against adults of the Eucalyptus snout-beetle Gonipterus scutellatus
Gyllenhal (Coleoptera: curculionidae). Journal of Pest Science, vol. 83, no. 3, pp. 297-305. http://dx.doi.org/10.1007/s10340010-0298-1.

ENRIQUE CABANILLAS, H., 2003. Susceptibility of the boll weevil to Steinernema riobrave and other entomopathogenic nematodes. Journal of Invertebrate Pathology, vol. 82, no. 3, pp. 188-197. http://dx.doi.org/10.1016/S0022-2011(03)00016-8. PMid:12676555.

GIOMETTI, F.H.C., LEITE, L.G., TAVARES, F.M., SCHMIT, F.S., BATISTA-FILHO, A. and DELL'ACQUA, R., 2011. Virulência de nematoides entomopatogênicos (Nematoda: Rhabditida) a Sphenophorus levis (Coleoptera: Curculionidae). Bragantia, vol. 70, no. 1, pp. 81-86. http://dx.doi.org/10.1590/ S0006-87052011000100013.

GREWAL, P.S., 2000. Anhydrobiotic potential an long term storage of entomopathogenic nematode (Rhabditida: steinernematidae). International Journal for Parasitology, vol. 30, no. 9, pp. 995-1000. http://dx.doi.org/10.1016/S0020-7519(00)00080-1. PMid:10980289.

HANKS, L.M., MILLAR, J.G., PAINE, T.D. and CAMPBELL, C.D., 2000. Classical biological control of the Australian Weevil Gonipterus scutellatus (Coleoptera: Curculionidae) in California. Environmental Entomology, vol. 29, no. 2, pp. 369-375. http:// dx.doi.org/10.1093/ee/29.2.369.

LEITE, L.G., MACHADO, L.A., AGUILLERA, M.M., RODRIGUES, R.C.D. and NEGRISOLI JUNIOR, A.S. ., 2003. Patogenicidade de Steinernema spp. e Heterorhabditis sp. (Nematoda: Rhabditida) a ninfas da cigarrinha da raiz da cana-de-açúcar (Mahanarva fimbriolata). Revista de Agricultura, vol. 78, no. 1, pp. 139-148.

MANACHINI, B., SCHILLACI, D. and ARIZZA, V., 2013. Biological responses of Rhynchophorus ferrugineus (Coleoptera: Curculionidae) to Steinernema carpocapsae (Nematoda: Steinernematidae). Journal of Economic Entomology, vol. 106, no. 4, pp. 1582-1589. http://dx.doi.org/10.1603/EC13031. PMid:24020269.

MAPONDERA, T.S., BURGESS, T., MATSUKI, M. and OBERPRIELER, R.G., 2012. Identification and molecular phylogenetics of the cryptic species of the Gonipterus scutellatus complex (Coleoptera: Curculionidae: Gonipterini). Austral Entomology, vol. 51, no. 3, pp. 175-188. http://dx.doi. org/10.1111/j.1440-6055.2011.00853.x.

NERMUT, J., ZEMEK, R., MRÁCEK, Z., PALEVSKY, E. and PUZA, V., 2019. Entomopathogenic nematodes as natural enemies for control of Rhizoglyphus robini (Acari: acaridae)? Biological Control, vol. 128, no. 1, pp. 102-110. http://dx.doi.org/10.1016/j. biocontrol.2018.10.003.

NGUYEN, K.B., GINARTE, C.M.A., LEITE, L.G., SANTOS, J.M. and HARAKAVA, R., 2010. Steinernema brazilense n. sp. (Rhabditida: Steinernematidae), a new entomopathogenic nematode from Mato Grosso, Brazil. Journal of Invertebrate Pathology, vol. 103, no. 1, pp. 8-20. http://dx.doi.org/10.1016/j. jip.2009.09.004. PMid:19772861.

POINAR JUNIOR, G.O. and GREWAL, P.S., 2012. History of entomopathogenic nematology. Journal of Nematology, vol. 44, no. 2, pp. 153-161. PMid:23482453.

REIS, A.R., FERREIRA, L., TOMÉ, M., ARAUJO, C. and BRANCO, M., 2012. Efficiency of biological control of Gonipterus platensis (Coleoptera: Curculionidae) by Anaphes nyteus (Hymenoptera: 
Mymaridae) in cold areas of the Iberian Peninsula: implications for defoliation and wood production in Eucalyptus globulus. Forest Ecology and Management, vol. 270, no. 1, pp. 216-222. http://dx.doi.org/10.1016/j.foreco.2012.01.038.

SHAPIRO-ILAN, D.I., STUART, R.J. and MCCOY, C.W., 2005. Targeted improvement of Steinernema carpocapsae for control of the pecan weevil, Curculio caryae (Horn) (Coleoptera: Curculionidae) through hybridization and bacterial transfer. Biological Control, vol. 34, no. 2, pp. 215-221. http://dx.doi. org/10.1016/j.biocontrol.2005.05.006.
SMITS, P.H., 1996. Pos-application persistence of entomopathogenic nematodes. Biocontrol Science and Technology, vol. 6, no. 3, pp. 379-388. http://dx.doi.org/10.1080/09583159631352.

WHITE, G.F., 1927. A method for obtaining infective nematode larvae from cultures. Science, vol. 66, no. 1709, pp. 302-303. http://dx.doi.org/10.1126/science.66.1709.302-a. PMid:17749713.

WOODRING, J.L. and KAYA, H.K., 1988. Steinernematid and heterorhabditid nematodes: a handbook of biology and techniques. Fayetteville: Arkansas Agricultural Experiment Station. Southern Cooperative Series Bulletin, no. 331. 